\title{
Why the Happiest Country in the World is Not a Muslim Country?
}

\author{
M Elfan Kaukab ${ }^{1 *}$, Z Sukawi², Sri Haryanto $^{3}$
}

\author{
${ }^{I}$ Faculty of Economics, Universitas Sains Al-Quran Jawa Tengah, Wonosobo, Indonesia \\ ${ }^{2}$ Faculty of Communication and Politics, Universitas Sains Al-Quran Jawa Tengah, Wonosobo, Indonesia \\ ${ }^{3}$ Faculty of Education and Teaching, Universitas Sains Al-Quran Jawa Tengah, Wonosobo, Indonesia \\ *Corresponding author. Email: elfan@unsiq.ac.id
}

\begin{abstract}
Religions, especially the Abrahamic that include Islam, claim that faith can bring happiness to mankind. However, Islamic countries are among the unhappiest countries on Earth. The purpose of this article is to examine the happiness determinant of Islamic society in Islamic countries based on Islamic economics framework to happiness. A literature review produces three keys to sustainable social and individual happiness: usury-free finance, Islamic entrepreneurship, and ZISWAF (Zakat, Infak, Sedekah, and Wakaf) empowerment. Based on this framework, we reviewed three global reports: World Happiness Report 2019, Global Entrepreneurship Monitor 2019, and Standard \& Poor 2019 Islamic Finance Outlook to see the Islamic countries' positions inside the three happiness elements. The result shows that Islamic entrepreneurship is relatively large. However, ZISWAF is still low, while interest-based finance is still large. This imperfect condition of the Islamic economy contributes to the low happiness of the Muslims in these countries. The findings implicate the importance of Islamic countries to participate in sharia banking and to motivate their citizens to pay zakat, sedekah (alms), infak, and wakaf. The fund will then be managed to effectively, efficiently, and transparently promote society's welfare.
\end{abstract}

Keywords: happiness per capita, Islamic economy, Zakat, Bhutan, social welfare

\section{INTRODUCTION}

The popularity of Bhutan, a small country in Central Asia, has been increasing lately due to its consecutive first position as a country with the happiest population. Bhutan's achievement is supported by its nation's development goal, which does not aim to build the economic but directly points to build happiness. The nations' success in prospering its citizens is not measured from economic prosperity, rather it is seen from the society's psychological welfare [1]. They care very little about wealth. They have a very short gap between the haves and the poor, do not pay attention to television, the internet, and radio. They also preserve $50 \%$ of their land to be used as national parks [2].

However, it should be acknowledged that a part of psychological welfare comes from the economy. Bhutan's economy is supported by the ever-increasing industrial sector. On the other hand, the farming sector continuously decreases. The tourism sector is the sole star sector sold overseas. Bhutan probably is a depiction of an underdeveloped country whose people are still "happy", before it finally becomes an industrial country, like other countries in the world. The farming sector decreases from $37.7 \%$ in 1997 to $20.9 \%$ in 2007 of Gross Domestic Product (GDP) [1]. Meanwhile, the tourism sector becomes less reliable as the tourists visiting the country are those of old ages and in smaller numbers[1].

There are various types of happiness. The literature identifies three types of it: hedonic happiness, eudemonic happiness, and engagement happiness [3], [4]. Hedonic happiness derives from the pleasure of life. Eudemonic happiness comes from the pleasure of developing oneself. Engagement happiness comes from the joy of performing something. What Bhutan feels are eudemonic and engagement happiness. It is different from what most countries pursue, hedonic happiness. When hedonic happiness, like wealth and freedom, is measured, Bhutan is not the best one. World Happiness Report 2019 places Bhutan in the 95 th position out of 156 surveyed countries [5].

It is obvious that several factors contribute to happiness. Genes and personalities are two relatively difficult factors to be altered and the two play roles in determining happiness [6]. Other factors include the conservative vs liberal government's policies [7] and significant life events [8]. World Happiness Report employs indicators such as per capita GDP, social support, healthy life expectancy, freedom to making choice, generosity, corruption-free, and utopic perception [5].

Religious teachings commonly teach their believers to pursue eudemonic and engagement happiness. The Eastern religions, like the one adhered to Bhutan, tend to less prioritize happiness coming from wealth, the source of hedonic happiness. This is different from Islamic teachings. Islam pursues the three kinds of happiness. Eudemonic happiness can be found in the effort to perfect faith and piety. Engagement happiness will be felt in the joy of ritual activity like praying (sholat) and fasting. Hedonic happiness can be found in life activities such as the joy of marriage [9], happiness coming from sharing [10], the joy of consuming [11], and happiness coming from physical 
activities [12]. In one of the hadiths, it is mentioned that the Prophet himself disliked poverty as it is close to heathenism. It can be argued that heaven itself is a form of hedonic happiness. Some people who cannot find hedonic life on earth can expect to see it in the afterlife through their engagement and eudemonic happiness.

Due to Islamic holistic nature, Islamic countries should have high positions in the World Happiness Report. Nevertheless, the existing statistics show otherwise. Out of the 156 countries, an Islamic country with the highest rank in the United Arab Emirates in the 21st position. It is followed by Saudi Arabia in the 28th and Qatar on the 29th. Afghanistan, Yemen, and Syria are in the 154th, 151st, and 149th respectively[5].

The situation emphasizes a huge gap between Islamic idealism and the reality in the world. It seems that when a country tries to pursue eudemonic and engagement happiness, like having a military war, it ignores hedonic happiness. The otherwise also happens. In this article, we argue that the three happiness can be obtained by using the Islamic economy framework. Two of the happiness factors in Islamic teachings are charity, both the obligatory (zakat) and the voluntary (Baqarah, 262, 277), and usury (riba)-free (Ali Imran, 130) [13]. This research attempts to explore and analyze the happiness-reducing factors related to that Islamic economy framework.

\section{LITERATURE REVIEW}

The concept of happiness has been explored for a very long time. In Ancient Greek, Aristotle defined happiness as "welfare combined with virtue, or independence, or mutually-agreed life, together with safety or possession abundance and slaves, and with the power to protect and utilize power" [14]. In this modern era, experts define happiness as "a prosperous condition characterized by relative provisions, with dominantly-consented emotions ranging from serenity to intense deep pleasures of life, and it is based on a natural desire of sustainability"[15]. It can be understood then that generally, happiness is sustainable psychological prosperity.

Islam teaches its followers to reach happiness in their life. One of the ways is practicing the Islamic economy by its guidance. Islamic economy is characterized by putting forward social justice as the main goal, unlike the capitalistic system that acquires and deposits wealth [16]. Putting social justice as the main goal has made the Islamic economy directly points the production and consumption to bring common prosperity. Aydin argued that the Islamic economy is a solution to the happiness crisis in capitalism [17]. Happiness crisis in capitalism is shown in several studies that suggested financial wealth is not analogous to happiness, whether directly or indirectly through effects like economic gaps and air pollution [18]-[21]. On the other hand, when economic development is not the main goal, there is an increase in happiness [22].

Aydin proposed G-donic happiness model as an Islamicbased happiness model oriented at holistic prosperity. The theory assumes that an individual comprises of seven elements: decision-making self, spiritual self, conscience, mind, animal spirit, self-centric spirit, and suppressor spirit.
Happiness can only be reached when all seven elements are understood prior to happiness-carrier decision-making [17]. Thus, the Islamic economy is a moral economy aimed at not only personal prosperity but also common prosperity [23]. The main characteristic of the Islamic economy is no-usury fund management, entrepreneurship, and charity. Fund management and entrepreneurship are part of the economy in general terms. Referring to World Happiness, economy and charity are two main factors of the seven happiness indicators[5]. These characteristics will be elaborated later on. In this article, the conceptual model of the relationship among usury-free fund management, entrepreneurship, and charity is shown in the following Figure 1.

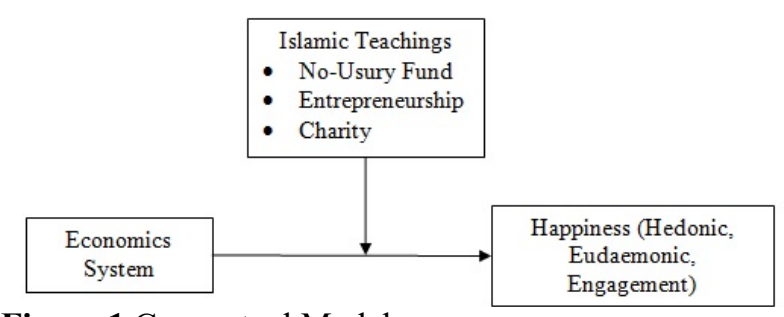

Figure 1 Conceptual Model

\subsection{No-Usury Fund}

A survey conducted in 2015 revealed that $9 \%$ of the Americans' income is used to pay interests [24]. Loan and interests seem to be the main characteristics of capitalism, in which materialistic values have burdened people with excessive debts. Research suggests that people with financial constraints tend to be more materialistic over time due to compulsive buying behavior, which means advancing wants instead of needs [25]. The more compulsive buying is done means the more an individual requires loans, which leads him/her into an endless debt cycle [26]. The relationship between debts and happiness is negative, which means the more debts an individual has, the less happiness/he feels [27].

In Islamic teachings, interest and fine are forbidden for a loan. It is referred to as riba/usury. Usury prohibition has actually existed even before the Islam era. Priest Anastasios of Cyprus in the 7th century, around the same time as Islam's birth, had regarded usury as injustice and that usury had become sources of wealth for the rich and the authorities [28]. Christian teachings also forbid usury [29]. However, Islam is the one that firmly prohibits usury in a loan, both for money and things. Islam also asserts that loans can only be given for fundamental and urgent things. The alternative for a no-usury fund is investment and sharing, in which both profit and loss are carried together. Sharia banking is a banking system developed without usury.

It is quite clear how usury avoidance is one of Islam's recipes to gain happiness [13]. First, without usury, a person will feel serene in fulfilling his/her needs and living his/her life because $\mathrm{s} / \mathrm{he}$ is free from the burden to pay the interest and fine of a loan, thus s/he reaches hedonic happiness. Second, a person can pursue the higher meaning of life as $\mathrm{s} / \mathrm{he}$ is free from the efforts to fulfill the needs to pay fine 
and interests, and therefore s/he finds eudemonic happiness. Third, with the absence of usury, a person will be able to enjoy his/her working hours without being chased by targets of paying the compiling fine and interests, and thus s/he fulfills the engagement happiness.

\subsection{Islamic Entrepreneurship}

Islam does not assert that a person should always be an entrepreneur. Islam encourages entrepreneurship as a halal life-activity with various regulations enabling it to bring happiness. Since entrepreneurship is considered as an important recipe for Islamic-dominated underdeveloped and developing countries, it is relevant to propose Islamic entrepreneurship as a recipe for happiness for Muslim countries.

As it is an activity with religious justification, Islamic entrepreneurship becomes a topic blooming recently. The Western academicians realize that they have been neglecting reliable and primary sources of Islamic entrepreneurship due to their wrong assumptions about nonconformity of Islam and entrepreneurship and their lack of knowledge of religious Muslim entrepreneurs' motives in business [30]. Generally, Islam teaches that entrepreneurship is a form of worship as it can bring prosperity into society directly through the economy or indirectly through the charity [31]. Therefore, Muslim entrepreneurs' motives and practices are rooted in religious rules, which in turn will characterize the Islamic economy in general [32].

Two significant concepts in Islamic entrepreneurship are fortune (rizq) and trust (tawakal). The first concept has orthographic similarity with the word 'risk', which is also the main concept in general entrepreneurship. However, it carries a more positive meaning, that is God's gifts. By reorienting risk into rizq, Islamic entrepreneurship becomes more positive and braver although both actually stand on uncertainty. The second concept, tawakal, means surrendering to God for the possible output after all efforts are done. Both concepts confirm the relationship between Islamic entrepreneurship and happiness. Rizq has enabled Muslim entrepreneurs to feel hedonic happiness, the results of their hard work are seen as God's gifts. Tawakal makes a Muslim entrepreneur consider entrepreneurship as a worshipping form, which gives him a sense of eudemonic happiness. It is strengthened by the fact that maximization profit is a way of Islamic entrepreneurship instead of the end goal of Islamic entrepreneurship. This is a way towards collective prosperity - the characteristic of the general Islamic economy [33]. Therefore, a Muslim entrepreneur will also be connected to the happiness he gains from sharing, which emerges from the charity concept.

\subsection{Charity}

Charity is a central element of Islamic teachings overtly stated in Al Qur'an [34]. From Islam's point of view, sharing is the summit of Islamic economy. Islam introduces the concept of zakat, infaq, sedekah, and wakaf (ZISWAF) as the forms of charity. Zakat is an obligatory payment of a certain sum of money to people in need. Infaq is a voluntary payment of free sum money. Sedekah (alms) is voluntary non-monetary giving to people in need. Wakaf(benefaction) is a property-giveaway for the public interest. All of those are seen as devotion forms reflecting an individual's faith quantity. The presence of strong justification in Islamic teachings for charity has made charity bears hedonic as well as eudemonic elements.

\section{METHOD}

To find out the conditions of the three determinants, we conducted a literature review on the multinational agency report documents. Reports reviewed are World Happiness Report 2019 [5], Global Entrepreneurship Monitor [35], and Standard \& Poor 2019 Islamic Finance Outlook [36]. The report's findings connected with concepts of no-usury fund, entrepreneurship, and charity to gain an understanding of the situations of these aspects in Islamic countries.

\section{RESULTS AND DISCUSSION}

\subsection{No-Usury Fund}

Reports and previous research show that Islamic countries still fight against usury. A study conducted in Malaysia revealed that $55 \%$ of the Muslim population hold that Islamic people always involve in usury from time to time, and only $25 \%$ think that usury is a good thing [37]. Meanwhile, a report by Standard \& Poor 2019 suggests that the existence of sharia banking is hardly noticed in the Africa continent, although almost half of its population are Muslim [36]. Sharia bonds also still neglected due to their small market share compared to usury-based conventional bonds [36]. The presence of the increased interests from conventional bonds and conventional banking explains why many Muslim countries are still unable to find happiness, whether individually or collectively.

Interest is an inseparable element of debt in capitalism. Although it is a compensation of inflation, administration, risks, and profits for the lender, interest has become an incriminating factor for debt and happiness. Besides, apart from the interest, there is also fine as another element of the capitalism debt system. As a consequence, the harder it is for a person to pay his/her debt, the bigger the burden is for $\mathrm{him} / \mathrm{her}$ in the future. It will more than what $\mathrm{s} / \mathrm{he}$ will have to pay if there is no fine.

The result of this review implies that Islamic countries still looking for their ideal economics system. Capitalists and Islamic systems exist and provided choices to follow by Moslems. Many, however, follow capitalist system, and hence, trapped inside interest and continued unhappiness.

\subsection{Islamic Entrepreneurship}

Islamic entrepreneurship in Muslim countries is quite promising nowadays. The Global Entrepreneurship Monitor 
has placed the Islamic countries in the entrepreneurship highest ranks. Out of the 54 surveyed countries, the first and second ranks are occupied by Islamic countries, Qatar and Indonesia. India, which also has a large Muslim population, is on the fifth rank. The United Arab Emirates is in the seventh position. Meanwhile, the United States of America, Japan, and China are in the 6th, 7th, and 11th positions respectively [35].

Entrepreneurship is a risk-taking life activity as it also potentially brings unhappiness. Studies suggest that entrepreneurs have their unhappiness in the form of anxiety about the future [38]. But they also have their own happiness. The entrepreneurs' happiness is due to satisfaction, low negative affection together with high positive affection, enjoying development, starting from zero, and so forth [39]. This is in accordance with the definition of engagement happiness.

This answers a question: why haven't Islamic countries been happy, despite the higher entrepreneurship activities? This could result from deep anxiety about the future. However, this could also result from the usury-based financial system, a low level of charity, or the mismanagement charity fund.

\subsection{Charity}

World Happiness Report includes charity as one of its dimensions to measure happiness. According to the report, charities in Islamic countries are in relatively low positions. Out of the 25 countries whose citizens do charity, Indonesia is the Islamic country with the highest position $(68,79 \%)$, in the seventh place. Qatar is far below it $(59,60 \%)$, in the 15th position, and it is followed by $\operatorname{Iran}(51,9 \%)$ [5].

Various studies suggest that charity significantly influences the givers' happiness, let alone the takers. A study in Finland reveals that people who give away charity are much happier than those who do not [40]. Interestingly, contrary to the common belief that hedonism is against charity, the main motive for charity in the developed countries is hedonism. For hedonic people, life is too short to be taken for granted, and one of their ultimate pleasures is spending money for others instead of for themselves [41]. Some theories have been proposed to explain this. A sharingbehavior might surface because someone wants to impress others that $\mathrm{s} / \mathrm{he}$ has bigger power and ability, or because $\mathrm{s} / \mathrm{he}$ wants to avoid social inequality that could inflict danger for himself/herself, or because sharing is an effort to maintain someone's positive mood [42].

The result of this study shows that a low level of charity in Islamic countries could confirm why happiness in these countries still low. This could also explain by mismanagement of the fund by deviant managers. The modern system of charity collection and management, based on good governance, especially the transparency principles, would help to increase the society's happiness level.

\section{CONCLUSION}

The purpose of this article is to examine the happiness determinant of Islamic society in Moslem countries based on three indicators: no-usury activities, entrepreneurship, and charity. The results show the gap between the Islamic economy's idealism and reality. Ideally Islamic economy should be able to bring Muslims into hedonic, eudemonic, and engagement happiness through no-usury activities, entrepreneurship, and charity. Our results suggest that Islamic countries are filled with usury-based financial institutions. On the other hand, entrepreneurship has actually performed well although in halfway. The charity flow that is expected as the end output of entrepreneurship has not flowed smoothly to the poor. This leads to social welfare for receivers and givers unobtained. Thus, countries with a significant amount of Muslim population should advance sharia banking and financial services. They also ought to eliminate usury practice while at the same time accentuate zakat, infak, sedekah, and wakaf obtained from Islamic economy and entrepreneurship in general.

\section{REFERENCES}

[1] R. Sharpley, Tourism Development and the Environment : Beyond Sustainability? London: Earthscan, 2009.

[2] J. Hindy, "10 Things Bhutan People Do Differently That Make Them The Happiest People," Lifehacks, 2019. [Online]. Available:

https://www.lifehack.org/articles/communication/8things-bhutan-people-differently-that-make-them-thehappiest-people.html. [Accessed: 06-Aug-2019].

[3] C. Peterson, N. Park, and M. E. Seligman, "Orientations to Happiness and Life Satisfaction: the Full Life versus the Empty Life," J. Happiness Stud., vol. 6 , pp. 25-41, 2005.

[4] E. Diener and M. Y. Chan, "Happy People Live Longer : Subjective Well-Being Contributes to Health and Longevity," Appl. Psychol. Heal. Well-Being, vol. 3, no. 1, pp. 1-43, 2011.

[5] J. F. Helliwell, R. Layard, and J. D. Sachs, "World Happiness Report 2019," 2019.

[6] M. Binder and A. Freytag, "Volunteering, Happiness and Public Policy,” Jena, 1207, 2012.

[7] A. Okulicz-Kozaryn, O. H. I. Iv, and D. R. Avery, "The Subjective Well-Being Political Paradox : Happy Welfare States and Unhappy Liberals,” J. Appl. Psychology, vol. 99, no. 6, pp. 1300-1308, 2014.

[8] E. Diener, R. Inglehart, and L. Tay, "Theory and Validity of Life Satisfaction Scales," Soc. Indic. Res., vol. 112 , no. 3 , pp. 497-527, 2013. 
[9] S. N. Rosifah, C. Nuryakin, and V. Handalusia, "Islamic Precepts for Marital Happiness in Indonesia: The Role of Religiousity and Spouse's Characteristics," Int. J. Bus. Soc., vol. 20, pp. 19-28, 2019.

[10] S. M. S. Baqutayan, M. I. A. Mohsin, A. M. Mahdzir, and A. S. Ariffin, "The psychology of giving behavior in Islam,” Sociol. Int. J., vol. 2, no. 2, pp. 8892, 2018.

[11] I. Amalia, W. Riani, and A. Julia, "The Influence of Religiosity Values on Happiness with Islamic Consuming Ethics as Moderator Variable," Procedia Soc. Behav. Sci., vol. 219, pp. 76-83, 2016.

[12] M. Achour, M. R. M. Nor, B. Amel, H. M. B. Seman, and M. Y. Z. Mohd Yusof, "Religious Commitment and its Relation to Happiness among Muslim Students : The Educational Level as Moderator," J. Relig. Health, vol. 56, no. 5, pp. 18701889, 2017.

[13] H. R. Alavi, "Correlatives of Happiness in the University Students of Iran (A Religious Approach), J J. Relig. Health, vol. 46, pp. 480-499, 2007.

[14] A. C. Michalos, "Education, Happiness and Wellbeing," in Connecting the Quality of Life Theory to Health, Well-Being and Education, Cham, Switzerland: Springer, 2017, pp. 277-299.

[15] S. Oishi and E. A. Gilbert, "Current and future directions in culture and happiness research," Curr. Opin. Psychol., vol. 8, pp. 54-58, 2016.

[16] A. Zaman and J. Qadir, "Putting Social Justice First: The Case of Islamic Economics,” J. Islam. Bank. Financ., pp. 87-99, 2017.

[17] N. Hachicha and A. Ben Amar, "Islamic finance and economic growth: The Malaysian case," in Islamic Economics : Theory, Policy and Social Justice, vol. 2, H. El-Karanshawy, A. Omar, T. Khan, S. S. Ali, H. Izhar, W. Tariq, K. Ginena, and B. al Quradaghi, Eds. Bloomsbury Qatar Foundation, 2015, pp. 173-182.

[18] R. A. Easterlin, "Happiness and Economic Growth: The Evidence," in Global Handbook of Quality of Life, Dordrecht: Springer, 2015, pp. 283299.

[19] S. Oishi and S. Kesebir, "Income Inequality Explains Why Economic Growth Does Not Always Translate to an Increase in Happiness," Psychol. Sci., vol. 26, no. 10, pp. 1630-1638, 2015.

[20] X. Zhang, X. Zhang, and X. Chen, "Happiness in the Air: How Does a Dirty Sky Affect Mental Health and Subjective Well-being?," J. Environ. Econ. Manage., vol. 85, pp. 81-94, 2017.

[21] J.-E. De Neve, G. Ward, F. De Keulenaer, B. Van Landeghem, G. Kavetsos, and M. I. Norton, "The Asymmetric Experience of Positive and Negative Economic Growth: Global Evidence Using Subjective Well-Being Data," Rev. Econ. Stat., vol. 100, no. 2, pp. 362-375, 2018.

[22] F. R. Campante and D. H. Yanagizawa-drott, "Does Religion Affect Economic Growth and Happiness? Evidence from Ramadan," Q. J. Econ., vol. 130, no. 2, pp. 615-658, 2015.

[23] H. Furqani, "Consumption and Morality : Principles and Behavioral Framework in Islamic Economics,” JKAU Islam. Econ., vol. 30, pp. 89-102, 2017.

[24] E. El Issa, "2015 American Household Credit Card Debt Study,” Nerdwallet Credit Card Blog, 2015. [Online]. Available:

https:/www.nerdwallet.com/blog/credit-carddata/household-credit-card-debt-study-2015/. [Accessed: 06-Aug-2019].

[25] S. M. Tully, H. A. L. E. Hershfield, and T. O. M. Meyvis, "Seeking Lasting Enjoyment with Limited Money : Financial Constraints Increase Preference for Material Goods Over Experiences," J. Consum. Res., vol. 42, no. 1, pp. 59-75, 2015.

[26] E. Jaspers and R. Pieters, "The Pursuit of Happiness and Quest For Wealth: Do Materialists Really Save Less and Borrow More, and If So Why?," in Advances in Consumer Research, vol. 44, P. Moreau and S. Puntoni, Eds. Duluth: Association for Consumer Research, 2016, pp. 503-504.

[27] A. Jantsch and R. Veenhoven, "Private Wealth and Happiness: A research synthesis using an online Findings-Archive," 03, 2018.

[28] P. Allen, "Giving: Some Tips for Happiness from Late Antiquity," in Ancient Routes to Happiness, P. Bosman, Ed. Pretoria: Classical Association of South Africa, 2017, pp. 120-134.

[29] S. Bayindir and M. Ustaoglu, "The issue of interest (riba) in the Abrahamic religions," Int. J. Ethics Syst., vol. 34, no. 3, pp. 282-303, 2018.

[30] V. Ramadani, L.-P. Dana, V. Ratten, and S. Tahiri, "The context of Islamic entrepreneurship and business : concept, principles and perspectives," Int. J. Bus. Glob., vol. 15, no. 3, pp. 244-261, 2015. 
[37] R. Fontaine, "Perception of Riba Among the Muslims in Malaysia : An Exploratory Study," J. Islam. Financ., vol. 8, no. 1, pp. 36-47, 2019.

[38] M. F. Bhuiyan and A. Ivlevs, "Microentrepreneurship and subjective well-being : Evidence from Rural Bangladesh," J. Bus. Ventur., vol. 34, pp. 625-645, 2019.

[39] J. Wiklund, B. Nikolaev, N. Shir, M. Foo, and S. Bradley, "Entrepreneurship and well-being : Past, present, and future," J. Bus. Ventur., vol. 34, pp. 579588, 2019.

[40] A. O. Tanskanen and M. Danielsbacka, "Do Volunteering and Charity Pay Off? Well-being Benefits of Participating in Voluntary Work and Charity for Older and Younger Adults in Finland," Res. Ageing Soc. Policy, vol. 4, no. 2, pp. 2-28, 2016.

[41] C. Mogilner and M. I. Norton, "Time, money, and happiness," Curr. Opin. Psychol., vol. 10, pp. 12-16, 2016.

[42] T. Lane, "How does happiness relate to economic behaviour? A review of the literature," J. Behav. Exp. Econ., vol. 68, pp. 62-78, 2017.

[36] Standard \& Poor Global, "Islamic Finance Outlook 2019," 2018. 